\title{
Correlation between HER-2/neu(erbB-2) expression level and therapeutic effect of combination treatment with HERCEPTIN and chemotherapeutic agents in gastric cancer cell lines
}

Hai Cui ${ }^{1 \dagger}$, Ying Cheng ${ }^{2+}$, Su-Zhou Piao ${ }^{1}$, Yun-Jie Xu ${ }^{3}$, Hong-Hua Sun ${ }^{1}$, Xian Cui ${ }^{1}$, Xiang-Zi Li ${ }^{1}$, Song-Nan Zhang ${ }^{1}$, Long-Zhen Piao ${ }^{1}$, Yong-Min Jin ${ }^{1}$, Zhen-hua Lin ${ }^{3}$ and Xiong-Hu Shen ${ }^{1 *}$

\begin{abstract}
Introduction: Although advanced gastric cancer has many limitations and response rate is marginal in chemotherapy. Overexpression of human epidermal growth factor receptor 2(HER-2/neu) gene and its protein are associated with increased cell division and a high rate of tumor growth and have been reported in several malignancies. Especially, approximately $30 \%$ of breast cancer patients have overexpression of HER-2/neu protein and the overexpression metastasize faster, induces resistance of the chemotherapy and down-regulate function of estrogen receptor. Recombinant humanized anti-HER2 antibody (Herceptin) inhibits proliferation of HER-2/neu overexpressing tumor cells and the use of that in combination in metastatic breast cancer have increased cytotoxicity of chemotherapeutic agents.

Methods: We evaluated the expression of HER-2/neu protein in gastric cell lines by FACS and then comparing the cytotoxicity in chemotherapeutics (doxorubicin, cisplatin, paclitaxel, 5-FU) alone and in combination with Herceptin according to the expression of HER-2/neu protein by MTT assay.

Results: 1. NCI-N87 (88\%) gastric cancer cell line and SK-BR-3 (89\%) breast cancer cell line with strong positivity of HER-2/neu expression. YBC-2 (55\%) and YBC-3 (48\%) gastric cancer cell line with intermediated, weak positivity respectively. Negative control U-87 MG (6\%) brain cancer cell line were showed low expression of HER-2/neu. 2. Cell growth was dose-dependently inhibited in HER-2/neu positive, control cell line SK-BR-3 by Herceptin treatment but not observed in HER-2/neu negative control cell line U-87 MG. Effective growth inhibition was not observed in gastric cancer cell lines with single treatment of Herceptin, all cell lines observed the dose-dependent growth inhibition to chemotherapeutic agents (doxorubicin, cisplatin, paclitaxel and 5-FU). 3. Combination of Herceptin with doxorubicin observed synergistic effects in all cancer cell lines except YBC-3, combination of Herceptin with cisplatin observed $\mathrm{NCl}-\mathrm{N} 87$ and SK-BR-3 and combination of Herceptin with paclitaxel observed synergistic effects in YBC-2. Combination of Herceptin with 5-FU observed antagonistic effects in all cancer cell lines.

Conclusions: According to HER-2/neu expression level, effect of anti-cancer agents was observed differently in combination of Herceptin with chemotherapeutic agents. This suggests that HER-2/neu expression level can be applied standard of combination drug selection in combination of Herceptin With chemotherapeutic agents in gastric cancer.
\end{abstract}

Keywords: HER-2/neu(erbB-2), HERCEPTIN, Gastric cancer, Combination treatment, Cl

\footnotetext{
* Correspondence: oncologist@live.cn

${ }^{\dagger}$ Equal contributors

'Department of Oncology, Affiliated Hospital of Yanbian University, Yanji City,

Jilin Province, People's Republic of China

Full list of author information is available at the end of the article
} 


\section{Introduction}

Since known that signal transduction pathways by growth factor and its receptor play an impotent role in the carcinogenic process many studies are being conducted. The HER-2/neu(erbB-2) protein, cell membrane glycoprotein, is a growth factor receptor has the activity of receptor tyrosine kinase [1]. HER2 has been frequently detected in a wide range of human tumors. Normal cell secretion associated with HER-2/neu protein, but destruction of normal cells control causing protein overexpression, increases the rate of cell division and growth induce precancerous changes [2].

The HER-2/neu(erbB-2) gene which is located on human chromosome 17q21 [3], which has partial homology with the epidermal growth factor receptor(EGFR) $[4,5]$. EGF (epidermal growth factor) receptor family has the activity of receptor tyrosine kinase and consisted of EGF receptor, c-erbB-2, c-erbB-3 and c-erbB-4 [6-8]. The HER-2/neu oncoprotein, encodes a p185kD membrane glycoprotein, receptor that is involved in the growth and diffentiation of the tumor cells and $25 \sim 30 \%$ overexpressed in breast, ovarian and gastric carcinomas [9-12] and the prognosis of these patients is poor [13-15].

Overexpression of HER-2/neu gene and it's protein are associated breast cancer patient's prognosis and therapy [16-18] and expression of HER-2/neu is strongly required for tumor growth [19]. Those suggest that HER-2/neu involved in the breast cancer occurrence, progression and malignant and HER-2/neu overexpression is more important than hormone receptors on the patients with lymph node metastasis [9]. Therefore, these therapeutic targets HER-2/neu protein drugs, recombinant humanized anti- HER-2/neu antibody - Herceptin, effective in the treatment of breast cancer has been reported [20].

Gastric cancer is the most prevalent cancer in the China. The occurrence of gastric cancer is the multistep carcinogenic process with variety genetic mutations. HER-2 status is correlated with the depth of invasion,
TNM stage, lymph node and distant metastasis of gastric cancer [21]. HER-2/neu over-expression is related to poor prognosis of gastric cancer but has a modest effect on survival in gastric cancer as an independent prognosis factor [22]. Herceptin ${ }^{\circ}$ as a cytostatic agent, the mono therapy efficient of antitumor effects cannot be expected but a lot of research is underway for combination therapy with other anticancer drugs or biologic agents. However, still not accurately study of combination therapy of Herceptin with anticancer drugs in gastric cell lines [13]. Therefore, in this study we investigate the effective combination of Herceptin (Trastuzumab, Genentech Inc, CA, USA) [23-25], targeting for HER-2/neu oncoprotein, with anti-cancer drugs in gastric cancer cell lines, depending on the HER-2/neu oncoprotein expression.

\section{Materials and methods \\ Cells}

Gastric cancer cell lines were used YBC-2, YBC-3 and NCI-N 87 cell lines. The YBC-2 and YBC-3 cell lines were established from intraperitoneal metastatic gastric cancer by Department of Pathology, Yanbian University. The NCI-N 87 cell line was established in the United State by NCI (National Cancer Institute, CRL5822, USA). The U-87 MG (ATCC, HTB14) brain tumor cell line and SK-BR-3 (ATCC, HTB30) breast cancer cell line were used for HER-2/neu protein expression positive and negative control, respectively.

These cell line were cultured use minimum essential media (MEM, GINCO BRL, Grand Island, NY, USA) which is containing inactivated (at $56^{\circ} \mathrm{C}$ for $30 \mathrm{~min}$ ) $10 \%$ fetal bovine serum (FBS, GINCO BRL, Grand Island, NY, USA), $100 \mathrm{unit} / \mathrm{ml}$ Penicillin and $0.1 \mathrm{mg} / \mathrm{ml}$ Streptomycin. All culture incubations were performed in a humidified $37^{\circ} \mathrm{C}, 5 \% \mathrm{CO}_{2}$ incubator.

\section{Drugs}

Herceptin, Humanoid recombinant HER-2/neu antibody, was from USA (Trastuzumab, $440 \mathrm{mg} / 20 \mathrm{ml}$, Genentech

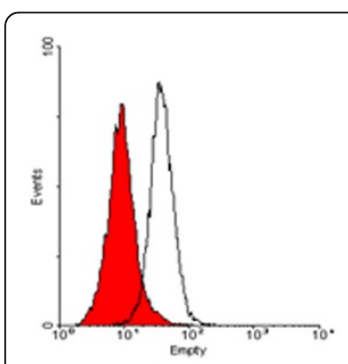

SK-BR-3
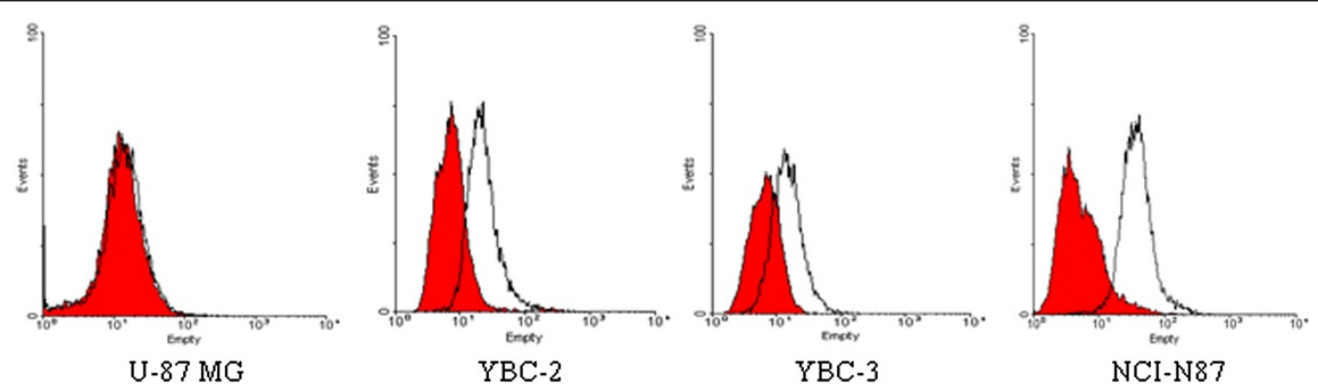

Figure 1 HER-2/neu expression in gastric cancer cell lines. The expression of HER2/neu protein in all cancer cell lines were measured by fluorescence-activated cell sorting analysis. The HER2/neu expression in three gastric cancer cell lines (YBC-2, YBC-3 and NCI-N87) were 48\% (weak ), 55\% (medium) and 88\% (strong), respectively. All groups of Isotype control were not more than 0.5\% (data not showed). As the positive control, SK-BR-3 of HER2/neu expression is 89\%. U-87 MG showed lower expression of HER2/neu (6\%) as negetive control. 


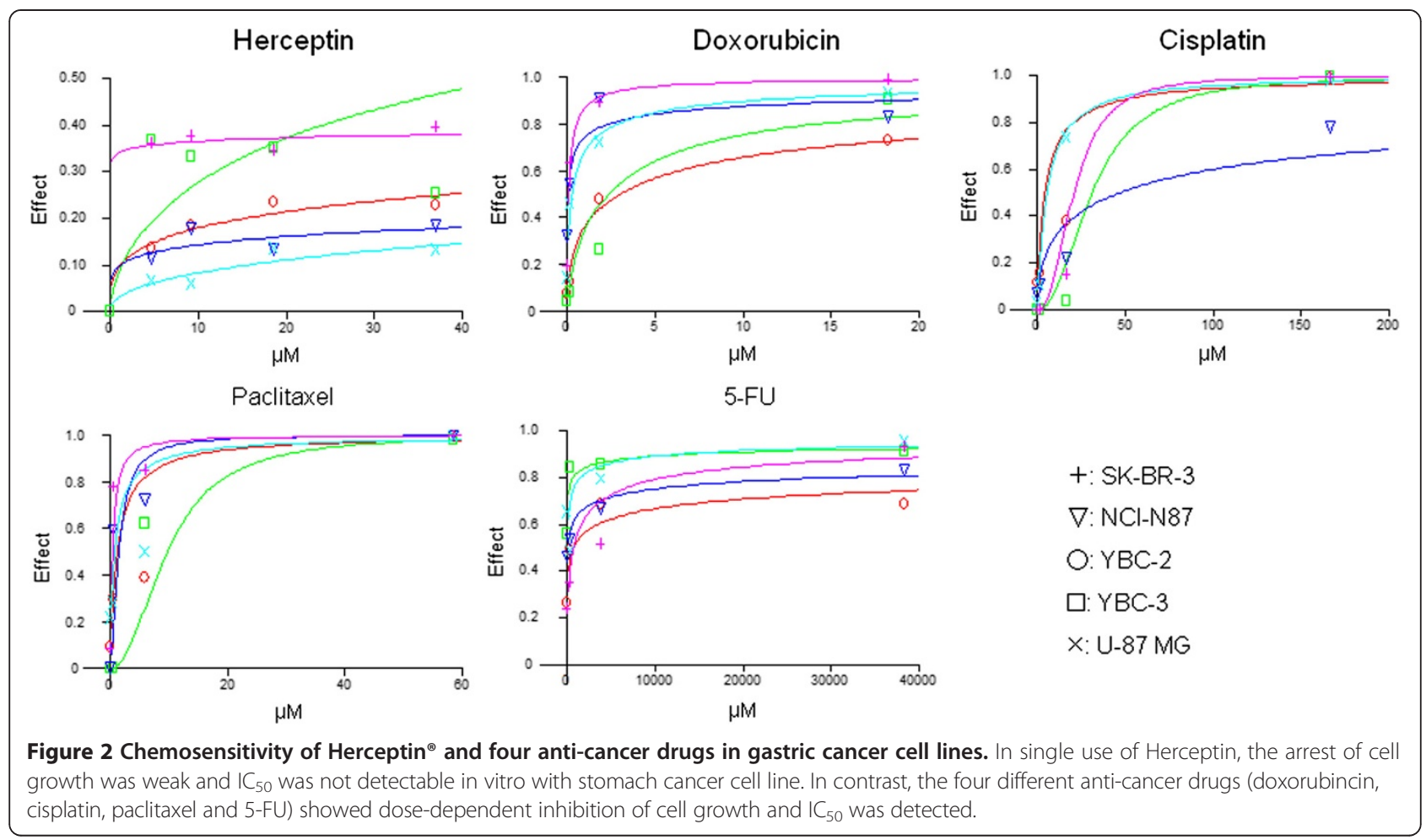

Inc., San Francisco, CA, USA), and recognized anticancer drugs, effect in gastric cancer, Adriamycin (Doxorubicin, $10 \mathrm{mg} / 5 \mathrm{ml}$ ), Cisplatin (Cisplatin, $10 \mathrm{mg} / \mathrm{vial}$ ), Taxol (Paclitaxel, $30 \mathrm{mg} /$ vial) and 5-FU (5-Flourouracil, $250 \mathrm{mg} /$ $5 \mathrm{ml}$ ) were from China. When doing experiment each drug was used diluted in cell culture media.

\section{FACS analysis (HER-2/neu protein expression)}

HER-2/neu(erbB-2) oncoprotein expression was done using Fluorescence-activated Cell Sorter (FACS, Becton Dickinson, U.S.A.) performed immunophenotyping in cell surface. Culture cells $\left(1 \times 10^{6}\right)$ were harvested after treat with trypsin-EDTA (GIBCOBRL, Grand Island, NY, USA) and incubated with the primary antibody, AntiHER-2/neu antibody (Mouse Monoclonal Antibody, LAB VISION, CA, USA), in a 1:200 dilution and $50 \mu \mathrm{l}$ for 1 hour at $4^{\circ} \mathrm{C}$. Stained cells were washed twice with cold PBS. Staining and washing were performed in PBS (phosphate-buffer solution, $\mathrm{pH} 7.6 \mathrm{Ca}^{++} \mathrm{Mg}^{++}$free, GIBCO BRL, Grand Island, NY, USA) 2\% FBS. After washing twice a secondary FITC-antimouse antibody (Anti-Mouse FITC-Conjugated antibody, Novocastra, USA) was used in a 1:40 dilution, and $50 \mu \mathrm{l}$ were incubated for 40 minute at $4^{\circ} \mathrm{C}$, after then washed twice with cold PBS. After completing the staining, filtration cell solution were used 40 um nylon mesh obtain the single cell suspended matter and doing analysis in the FACS.
MTT assay (in vitro Herceptin and chemotherapeutic agents sensitivity test in gastric cancer cell lines)

The MTT assay has been used for in vitro drug sensitivity test in gastric cancer cell lines. MTT dye [3-(4,5-dimethyl thiazol-2-yl)-2,5-diphenyl tetrazolium bromide] is reduced to formazan (a dark purple water insoluble compound) by the succinate dehydrogenase system of active mitochondria, and hence, specifically used to the optical density (OD) of the wells was measured in an enzyme-linked immunosorbent assay (ELISA) reader Sunrise (TECAN) at

Table 1 IC30 and IC50 of five anti-cancer agents against YBC-2, YBC-3, NCI-N87, U-87 MG and SK-BR-3 cell lines

\begin{tabular}{lccccc}
\hline Anticancer agents & \multicolumn{5}{c}{ Cell lines $\left(\mathbf{I C}_{\mathbf{3 0}}\right) \boldsymbol{\mu} \boldsymbol{M}$} \\
\cline { 2 - 6 } & YBC-2 & YBC-3 & NCI-N87 & SK-BR-3 & U-87 MG \\
\hline Herceptin & 82.36 & 11.83 & 1326.72 & 0.02 & 289.09 \\
Doxorubicin & 0.6 & 0.76 & 0.01 & 0.03 & 0.07 \\
Cisplatin & 1.79 & 21 & 9.28 & 14.54 & 2.58 \\
Paclitaxel & 0.52 & 6.45 & 0.86 & 0.19 & 0.3 \\
5-FU & 33.11 & 0.22 & 4.11 & 148.75 & 5.51 \\
\hline Anticancer agents & \multicolumn{5}{c}{ Cell lines (IC $\mathbf{5 0}) \boldsymbol{\mu M}$} \\
& YBC-2 & YBC-3 & NCI-N87 & SK-BR-3 & U-87 MG \\
\hline Doxorubicin & 2.93 & 2.31 & 0.07 & 0.1 & 0.29 \\
Cisplatin & 4.51 & 30.73 & 45.86 & 5.65 & 20.63 \\
Paclitaxel & 1.24 & 9.61 & 1.49 & 0.42 & 0.79 \\
5-FU & 752.04 & 4.74 & 119.61 & 753.42 & 46.58 \\
\hline & \multicolumn{5}{c}{}
\end{tabular}


$560 \mathrm{~nm}$. The OD correlated linearly with the number of viable cells. Cells were plated at $180 \mathrm{ul}$ media of $1 \times 10^{4}$ cells per well in a 96 well multi-well plate and incubated for $24 \mathrm{~h}$ at $37^{\circ} \mathrm{C}$ and $5 \% \mathrm{CO}_{2}$.

For single drug sensitivity test, two methods were applied. First, Herceptin $(4.625,9.25,18.5,37 \mu \mathrm{M})$, doxorubicin $(0.0183,0.183,1.83,18.3 \mu \mathrm{M})$, cisplatin $(0.166$, 1.666, 16.66, $166.6 \mu \mathrm{M})$, paclitaxel $(0.0585,0.585,5.85$, $58.5 \mu \mathrm{M})$ and 5-FU (38.43, 384.37, 3843.78, $38437.8 \mu \mathrm{M})$ were diluted in $20 \mu \mathrm{l}$ media and added to the plates and incubated for 4 days. Control group were added only media without the drugs and incubated same durations. Second, the synergistic effect of the combination therapy with a combination of Herceptin + Doxorubicin, Herceptin + Cisplatin, Herceptin + Paclitaxel and Herceptin + 5- FU.
When combination treatment Herceptin and each anticancer drug performed sensitivity test, fixed molar concentration percentage of both drugs, after then adding $50 \mu \mathrm{l}$ MTT, MTT was dissolved in phosphate buffer to the concentration of $2 \mathrm{mg} / \mu \mathrm{l}$, added to each well and incubated 4 hours more. After removing the supernatant, placed $150 \mu \mathrm{l}$ DMSO (Dimethyl sulfoxide, Sigma, USA) in each well and gently shaking about 15 minutes to dissolve the generated formazan. The optical density (OD) of the wells was measured in an enzyme-linked immunosorbent assay (ELISA) reader at 562 and $720 \mathrm{~nm}$. The malignant cell survival was calculated by the equation (OD of drug well- OD of blank well/mean OD of control well - OD of blank well) $\times 100 \%$. MTT assay was performed and repeated three times for each dose of the drug (5 well) the results were analyzed to obtain the average.

Table 2 Calculated values for the Combination Index as a growth inhibitory effect of combination treatment with Herceptin ${ }^{\circledR}$ and Doxorubicin in gastric cancer cell lines

\begin{tabular}{|c|c|c|c|c|c|c|}
\hline \multirow{2}{*}{$\begin{array}{l}\text { YBC-2 } \\
\text { Drug }\end{array}$} & \multicolumn{3}{|c|}{ Combination Index Value } & \multicolumn{3}{|c|}{ Parameter $(\mu \mathrm{M})$} \\
\hline & ED50 & ED75 & ED90 & $\mathrm{Dm}$ & $\mathrm{m}$ & $r$ \\
\hline DOX & & & & 2.93 & 0.54 & 0.98 \\
\hline HER & & & & 1201.02 & 0.32 & 0.91 \\
\hline DOX + HER & 0.09 & 0.05 & 0.03 & 0.25 & 0.74 & 0.96 \\
\hline Diagnosis combined effect & synergy & synergy & synergy & & & \\
\hline YBC-3 & \multicolumn{3}{|c|}{ Combination Index Value } & \multicolumn{3}{|c|}{ Parameter $(\mu \mathrm{M})$} \\
\hline Drug & ED50 & ED75 & ED90 & Dm & m & $r$ \\
\hline DOX & & & & 2.310 & 0.768 & 0.946 \\
\hline HER & & & & 46.063 & 0.623 & 0.970 \\
\hline DOX + HER & 0.266 & 0.598 & 1.377 & 0.406 & 0.469 & 0.925 \\
\hline Diagnosis combined effect & synergy & synergy & antagonism & & & \\
\hline $\mathrm{NCl}-\mathrm{N} 87$ & \multicolumn{3}{|c|}{ Combination Index Value } & \multicolumn{3}{|c|}{ Parameter $(\mu \mathrm{M})$} \\
\hline Drug & ED50 & ED75 & ED90 & $\mathrm{Dm}$ & $\mathrm{m}$ & $r$ \\
\hline DOX & & & & 0.070 & 0.398 & 0.864 \\
\hline HER & & & & 113350 & 0.191 & 0.635 \\
\hline DOX + HER & 0.005 & 0.004 & 0.003 & 0.000 & 0.437 & 0.995 \\
\hline Diagnosis combined effect & synergy & synergy & synergy & & & \\
\hline U-87 MG & \multicolumn{3}{|c|}{ Combination Index Value } & \multicolumn{3}{|c|}{ Parameter $(\mu \mathrm{M})$} \\
\hline Drug & ED50 & ED75 & ED90 & $\mathrm{Dm}$ & $\mathrm{m}$ & $r$ \\
\hline DOX & & & & 0.295 & 0.620 & 0.997 \\
\hline HER & & & & 1845.5 & 0.457 & 0.860 \\
\hline DOX + HER & 0.441 & 0.435 & 0.448 & 0.101 & 0.589 & 0.992 \\
\hline Diagnosis combined effect & synergy & synergy & synergy & & & \\
\hline SK-BR-3 & \multicolumn{3}{|c|}{ Combination Index Value } & \multicolumn{3}{|c|}{ Parameter $(\mu \mathrm{M})$} \\
\hline Drug & ED50 & ED75 & ED90 & Dm & $\mathrm{m}$ & $r$ \\
\hline DOX & & & & 0.103 & 0.832 & 0.998 \\
\hline HER & & & & 1424000 & 0.046 & 0.435 \\
\hline DOX + HER & 0.046 & 0.074 & 0.117 & 0.005 & 0.616 & 0.985 \\
\hline Diagnosis combined effect & synergy & synergy & synergy & & & \\
\hline
\end{tabular}

DOX, Doxorubicin; HER, Herceptin. 


\section{$\mathrm{Cl}$ value calculation after combination therapy}

CI (Combination index) was obtained by the formula of Chou-Talalay, was calculated from the value of IC50 $(\mathrm{Dm})$ compared the efficacy and capacity curve (the $\mathrm{m}$ value). Classic formula of the Isobologram $(\mathrm{CI}=1)$ was as follows.

$$
C I=(D)_{1} /(D x)_{1}+(D)_{2} /(D x)_{2}
$$

Denominator of $(\mathrm{Dx})_{1}$ and $(\mathrm{Dx})_{2}$ were indicate the percentage cytotoxicity of when treated with single drug alone; numerator of $(D)_{1}$ and $(D)_{2}$ were indicate the percentage cytotoxicity of when treated with both drugs.

$$
D x=D m[f a /(1-f a)]^{1 m}
$$

Dm is the median-effect dose (IC50), this calculated by median-effect plot of the $\mathrm{X}$-intercept from the antilog.

$$
\mathrm{X}=\log (D) \text { versus } \mathrm{Y}=\log [\mathrm{f} a /(1-\mathrm{f} a)]
$$

$\mathrm{m}$ is the slope of the median-effect plot. Multiple drug effect analysis using Calcusyn (Biosoft, Cambridge, UK), were calculated values of $\mathrm{m}, \mathrm{Dm}, \mathrm{Dx}$, and CI. (Dx) 1 and (Dx) 2 were calculated using the Chou-Talalay medianeffect formula. CI $<1, \mathrm{CI}=1, \mathrm{CI}>1$ were called synergism, summation, and antagonism effects respectively.

\section{Statistical evaluation}

Statistical analyses of the data were performed using the two-tailed Student $t$-test (SPSS 13.0 software; SPSS, Chicago, IL). $p$ values less than 0.05 were considered statistically significant. Analysis of variance (ANOVA) was used for multiple group comparisons to determine the potential antitumor effects between groups.

\section{Results}

HER-2/neu expression in gastric cancer cell lines by FACS The expression of HER2/neu protein was analysed in three different stomach cancer cell lines (YBC-2, YBC-3 and NCI-N87). The expression of this proteinis $48 \%$ (weak), 55\% (medium) and 88\% (strong) in YBC-2, YBC3 and NCI-N87, respectively. The expression of this protein was $89 \%$ in positive breast cancer cell line SK-BR-3, and $6 \%$ in negative brain tumor cell line U-87 MG (Figure 1).

The sensitivity of stomach cancer cell line to Herceptin and anti-cancer drug and the analysis of sensitivity to single drug treatment in vitro

In single use of Herceptin, the arrest of cell growth was weak and $\mathrm{IC}_{50}$ was not detectable in vitro with stomach cancer cell line (Figure 2). In contrast, the four different anti-cancer drugs (doxorubincin, cisplatin, paclitaxel and
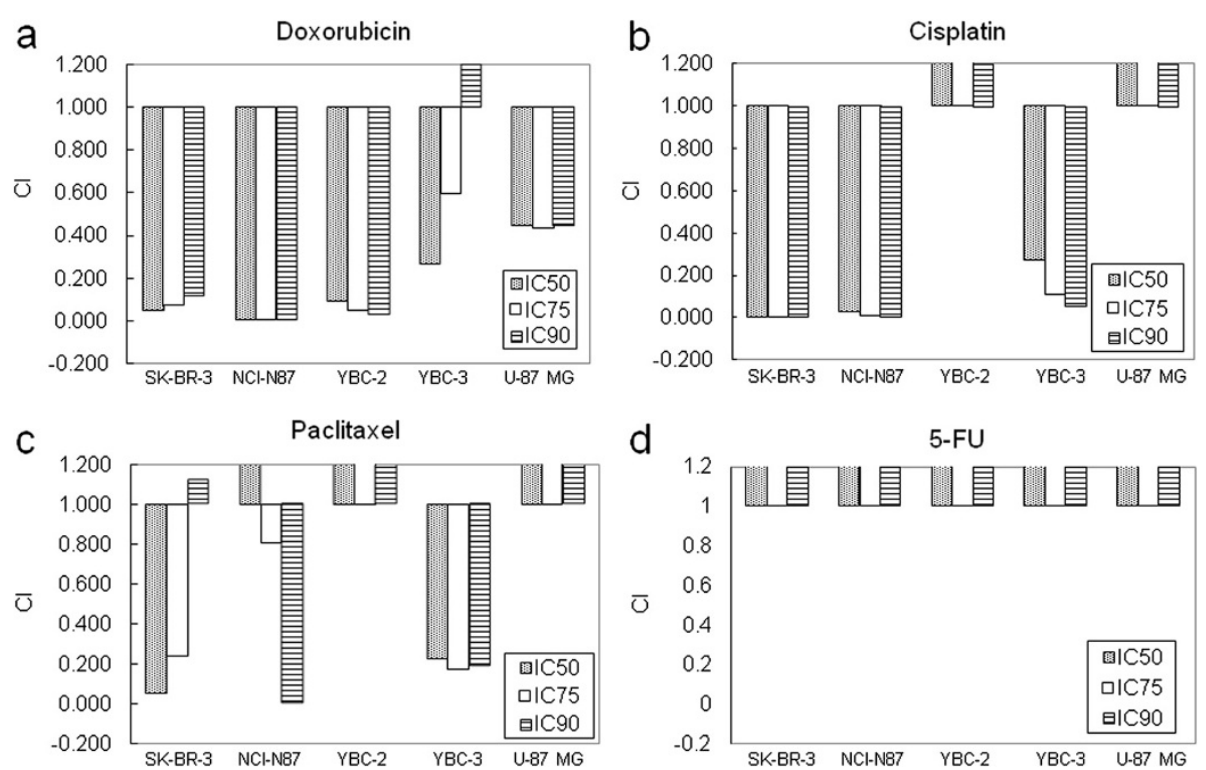

d

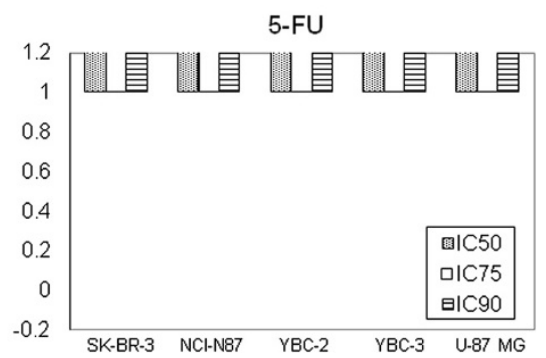

Figure 3 Combination Index as a growth inhibitory effect of combination treatment with Herceptin ${ }^{\circledR}$ and anti-cancer agents. a. In the combination of Herceptin and doxorubincin treatment, the synergetic effect was observed in YBC-2 and NCl-N87 cells, but not in YBC-3 cell line. b. In the combination of herceptin and cisplatin, the synergetic effects were observed in SK-BR-3, NCI-N87 and YBC-3 cell lines $(\mathrm{Cl}<1)$. However, the inhibitory effects were observed in YBC-2 and U-87 MG cell lines $(\mathrm{Cl}>1)$. c. The treatment of Herceptin and paclitaxel, in YBC-3 and U-87 MG cell lines, the inhibitory effects were observed $(\mathrm{Cl}>1)$, however, in $\mathrm{YBC}-3$ cell line, the synergetic effect was observed $(\mathrm{Cl}<1)$. In SK-BR-3 and NCl-87 cell lines, the effects were different depends on the dose of the drugs. $\mathbf{d}$. In the combination of Herceptin and 5-FU, the inhibitory effects were observed in all of the cell lines $(\mathrm{Cl}>1)$. 
5-FU) showed dose-dependent inhibition of cell growth and $\mathrm{IC}_{50}$ was detected (Table 1, Figure 2).

The effect of the combination of Herceptin and anti-cancer drugs

In the combination of Herceptin and doxorubincin treatment, the synergetic effect was observed in YBC-2 and NCI-N87 cells, but not in YBC-3 cell line which has weak expression of HER2/neu protein (Table 2, Figure 3a, $P<$ $0.05)$. In the combination of herceptin and cisplatin, the synergetic effects were observed in SK-BR-3, NCI-N87 and YBC-3 cell lines $(\mathrm{CI}<1, P<0.05)$. However, the inhibitory effects were observed in YBC-2 and U-87 MG cell lines (Combination Index $>1, P<0.05$ ) (Table 3, Figure 3b). The treatment of Herceptin and paclitaxel, in YBC-3 and U-87
MG cell lines, the inhibitory effects were observed $(\mathrm{CI}>1)$, however, in YBC-3 cell line, the synergetic effect was observed $(\mathrm{CI}<1, P<0.05)$. In SK-BR-3 and NCI-87 cell lines, the effects were different depends on the dose of the drugs (Table 4, Figure 3c). In the combination of Herceptin and 5 -FU, the inhibitory effects were observed in all of the cell lines $(\mathrm{CI}>1, P<0.05)$ (Table 5, Figure $3 \mathrm{~d}$ ).

\section{Discussion}

The overexpression of the growth factors or the receptors of the growth factors in the signaling pathways, will not only highly affect cell growth but also induce tumorigenesis. Pro-oncogenes play important roles during cell growth, development and differentiation. They also involved in the function of the growth factors and their

Table 3 Calculated values for the Combination Index as a growth inhibitory effect of combination treatment with Herceptin ${ }^{\circledast}$ and Cisplatin in gastric cancer cell lines

\begin{tabular}{|c|c|c|c|c|c|c|}
\hline \multirow{2}{*}{$\begin{array}{l}\text { YBC-2 } \\
\text { Drug }\end{array}$} & \multicolumn{3}{|c|}{ Combination Index Value } & \multicolumn{3}{|c|}{ Parameter $(\mu \mathrm{M})$} \\
\hline & ED50 & ED75 & ED90 & $\mathrm{Dm}$ & $\mathrm{m}$ & $r$ \\
\hline CDDP & & & & 4.512 & 0.921 & 0.882 \\
\hline HER & & & & 1201.0 & 0.316 & 0.915 \\
\hline CDDP + HER & 1.375 & 2.707 & 5.337 & 2.232 & 0.587 & 0.965 \\
\hline Diagnosis combined effect & antagonism & antagonism & antagonism & & & \\
\hline YBC-3 & \multicolumn{3}{|c|}{ Combination Index Value } & \multicolumn{3}{|c|}{ Parameter $(\mu \mathrm{M})$} \\
\hline Drug & ED50 & ED75 & ED90 & Dm & $\mathrm{m}$ & $r$ \\
\hline CDDP & & & & 30.733 & 2.227 & 0.929 \\
\hline HER & & & & 46.063 & 0.623 & 0.970 \\
\hline CDDP + HER & 0.274 & 0.110 & 0.054 & 12.091 & 1.472 & 0.998 \\
\hline Diagnosis combined effect & synergy & synergy & synergy & & & \\
\hline $\mathrm{NCl}-\mathrm{N} 87$ & \multicolumn{3}{|c|}{ Combination Index Value } & \multicolumn{3}{|c|}{ Parameter $(\mu \mathrm{M})$} \\
\hline Drug & ED50 & ED75 & ED90 & Dm & $\mathrm{m}$ & $r$ \\
\hline CDDP & & & & 45.86 & 0.53 & 0.93 \\
\hline HER & & & & $1.13 E+05$ & 0.19 & 0.63 \\
\hline CDDP + HER & 0.03 & 0.01 & 0.01 & 0.83 & 0.88 & 0.96 \\
\hline Diagnosis combined effect & synergy & synergy & synergy & & & \\
\hline U-87 MG & \multicolumn{3}{|c|}{ Combination Index Value } & \multicolumn{3}{|c|}{ Parameter $(\mu \mathrm{M})$} \\
\hline Drug & ED50 & ED75 & ED90 & $\mathrm{Dm}$ & m & $r$ \\
\hline CDDP & & & & 5.65 & 1.08 & 0.98 \\
\hline HER & & & & 1845.53 & 0.46 & 0.86 \\
\hline CDDP + HER & 9.18 & 9.85 & 10.58 & 2.56 & 1.01 & 0.99 \\
\hline Diagnosis combined effect & antagonism & antagonism & antagonism & & & \\
\hline SK-BR-3 & \multicolumn{3}{|c|}{ Combination Index Value } & \multicolumn{3}{|c|}{ Parameter $(\mu \mathrm{M})$} \\
\hline Drug & ED50 & ED75 & ED90 & Dm & m & $r$ \\
\hline CDDP & & & & 20.63 & 2.42 & 0.94 \\
\hline HER & & & & $1.42 E+06$ & 0.05 & 0.43 \\
\hline CDDP + HER & 0 & 0 & 0 & 1.45 & 1.44 & 0.99 \\
\hline Diagnosis combined effect & synergy & synergy & synergy & & & \\
\hline
\end{tabular}

$C D D P$, Cisplatin; HER, Herceptin. 
Table 4 Calculated values for the Combination Index as a growth inhibitory effect of combination treatment with Herceptin ${ }^{\circledR}$ and Paclitaxel in gastric cancer cell lines

\begin{tabular}{|c|c|c|c|c|c|c|}
\hline \multirow{2}{*}{$\begin{array}{l}\text { YBC-2 } \\
\text { Drug }\end{array}$} & \multicolumn{3}{|c|}{ Combination Index Value } & \multicolumn{3}{|c|}{ Parameter $(\mu \mathrm{M})$} \\
\hline & ED50 & ED75 & ED90 & Dm & m & $r$ \\
\hline TAX & & & & 1.24 & 0.98 & 0.9 \\
\hline HER & & & & 1201.02 & 0.32 & 0.92 \\
\hline TAX + HER & 6.03 & 14.77 & 36.21 & 0.85 & 0.54 & 0.82 \\
\hline Diagnosis combined effect & antagonism & antagonism & antagonism & & & \\
\hline YBC-3 & \multicolumn{3}{|c|}{ Combination Index Value } & \multicolumn{3}{|c|}{ Parameter $(\mu \mathrm{M})$} \\
\hline Drug & ED50 & ED75 & ED90 & Dm & $\mathrm{m}$ & $r$ \\
\hline TAX & & & & 9.609 & 2.129 & 0.940 \\
\hline HER & & & & 46.063 & 0.623 & 0.970 \\
\hline TAX + HER & 0.225 & 0.172 & 0.185 & 7.010 & 1.220 & 0.889 \\
\hline Diagnosis combined effect & synergy & synergy & synergy & & & \\
\hline $\mathrm{NCl}-\mathrm{N} 87$ & \multicolumn{3}{|c|}{ Combination Index Value } & \multicolumn{3}{|c|}{ Parameter $(\mu \mathrm{M})$} \\
\hline Drug & ED50 & ED75 & ED90 & Dm & m & $r$ \\
\hline TAX & & & & 1.49 & 1.56 & 0.96 \\
\hline HER & & & & 113350 & 0.19 & 0.63 \\
\hline TAX + HER & 1747.94 & 0.81 & 0 & 858.42 & -0.16 & 0.90 \\
\hline Diagnosis combined effect & antagonism & synergy & synergy & & & \\
\hline U-87 MG & \multicolumn{3}{|c|}{ Combination Index Value } & \multicolumn{3}{|c|}{ Parameter $(\mu \mathrm{M})$} \\
\hline Drug & ED50 & ED75 & ED90 & Dm & m & $\mathrm{r}$ \\
\hline TAX & & & & 0.79 & 0.89 & 0.87 \\
\hline HER & & & & 1845.53 & 0.46 & 0.86 \\
\hline TAX + HER & 361.02 & 1571.47 & 6840.35 & 1.27 & 0.41 & 0.89 \\
\hline Diagnosis combined effect & antagonism & antagonism & antagonism & & & \\
\hline SK-BR-3 & \multicolumn{3}{|c|}{ Combination Index Value } & \multicolumn{3}{|c|}{ Parameter $(\mu \mathrm{M})$} \\
\hline Drug & ED50 & ED75 & ED90 & $\mathrm{Dm}$ & $\mathrm{m}$ & $r$ \\
\hline TAX & & & & 0.42 & 1.11 & 0.96 \\
\hline HER & & & & $1.42 E+06$ & 0.05 & 0.43 \\
\hline TAX + HER & 0.05 & 0.24 & 1.12 & 0 & 0.44 & 0.88 \\
\hline Diagnosis combined effect & synergy & synergy & antagonism & & & \\
\hline
\end{tabular}

TAX, Paclitaxel; HER, Herceptin.

receptors, or other signaling pathways and induce the abnormal cell growth and induce the cells become tumor cells. The overexpression of receptors of growth factors, such as FGF-5, TGF-a, EGF, will induce tumorigenesis.

After HER-2/neu protein was first discovered in breast cancer cells [4], this protein has been actively studied in breast cancer field. In about $30 \%$ of total breast cancer patients, Her-2/neu is overexpressed. Many in vitro and in vivo studies have shown that the increased level of HER2 was associated with the early stage breast cancer [26], recurrence rates, cancer metastasis and the decreased efficiency of hormone-based therapy [5,27]. HER-2 has been considered as factor for poor prognosis. HER-2 oncogene is located on the chromosome seventeen q21 and structurally has close relationship with
EGFR gene which is locate in chrosome seven and v-erbB oncogene. Point mutation of HER-2 in transmembrane domain forms $4.8 \mathrm{~kb}$ mRNA and $185 \mathrm{Kd}$ glycoprotein which belongs to tyrosine kinases.

Overexpression of HER-2 protein is not discovered in normal tissues. In contrast, it is overexpressed in primary and metastatic cancer tissues which have been considered as the target of therapy. HER-2/neu might be a useful target for immunotherapy in colorectal carcinoma, anti-HER2 anti-CD3 BsAb exerting clear antitumor effects [28]. In vitro and in vivo studies showed that inhibition of HER-2 with anti-HER2 antibody showed high toxicity to breast cancer cells [29]. Herceptin is anti-HER2 antibody. It was developed as the combination of human immunoglobulin with murine antigen 
Table 5 Calculated values for the Combination Index as a growth inhibitory effect of combination treatment with Herceptin ${ }^{\circledR}$ and 5-FU in gastric cancer cell lines

\begin{tabular}{|c|c|c|c|c|c|c|}
\hline \multirow{2}{*}{$\begin{array}{l}\text { YBC-2 } \\
\text { Drug }\end{array}$} & \multicolumn{3}{|c|}{ Combination Index value } & \multicolumn{3}{|c|}{ Parameter $(\mu \mathrm{M})$} \\
\hline & ED50 & ED75 & ED90 & Dm & m & $r$ \\
\hline 5-FU & & & & 752.04 & 0.27 & 0.94 \\
\hline HER & & & & 1201.02 & 0.32 & 0.91 \\
\hline 5-FU + HER & 8060.81 & 1620.97 & 325.97 & 285.29 & 0.45 & 1 \\
\hline Diagnosis combined effect & Antagonism & Antagonism & Antagonism & & & \\
\hline YBC-3 & \multicolumn{3}{|c|}{ Combination Index value } & \multicolumn{3}{|c|}{ Parameter $(\mu \mathrm{M})$} \\
\hline Drug & ED50 & ED75 & ED90 & $\mathrm{Dm}$ & $\mathrm{m}$ & $r$ \\
\hline 5-FU & & & & 4.739 & 0.279 & 0.920 \\
\hline HER & & & & 46.063 & 0.623 & 0.970 \\
\hline 5-FU + HER & 75054 & $2.89 E+05$ & $1.13 E+06$ & 71.077 & 0.207 & 0.928 \\
\hline Diagnosis combined effect & antagonism & antagonism & antagonism & & & \\
\hline $\mathrm{NCl}-\mathrm{N} 87$ & \multicolumn{3}{|c|}{ Combination Index value } & \multicolumn{3}{|c|}{ Parameter $(\mu \mathrm{M})$} \\
\hline Drug & ED50 & ED75 & ED90 & $\mathrm{Dm}$ & $\mathrm{m}$ & $\mathbf{r}$ \\
\hline 5-FU & & & & 119.61 & 0.25 & 0.97 \\
\hline HER & & & & $1.1 \mathrm{E}+05$ & 0.19 & 0.63 \\
\hline 5-FU + HER & $1.9 \mathrm{E}+17$ & $3.2 \mathrm{E}+02$ & $5.3 E+29$ & $3.7 \mathrm{E}+14$ & -0.02 & 0.87 \\
\hline Diagnosis combined effect & antagonism & antagonism & antagonism & & & \\
\hline U-87 MG & \multicolumn{3}{|c|}{ Combination Index value } & \multicolumn{3}{|c|}{ Parameter $(\mu \mathrm{M})$} \\
\hline Drug & ED50 & ED75 & ED90 & $\mathrm{Dm}$ & m & $\mathrm{r}$ \\
\hline 5-FU & & & & 46.58 & 0.4 & 0.84 \\
\hline HER & & & & 1845.53 & 0.46 & 0.86 \\
\hline 5-FU + HER & 25540 & 4940.8 & 955.81 & 6.48 & 0.98 & 1 \\
\hline Diagnosis combined effect & antagonism & antagonism & antagonism & & & \\
\hline SK-BR-3 & \multicolumn{3}{|c|}{ Combination Index value } & \multicolumn{3}{|c|}{ Parameter $(\mu \mathrm{M})$} \\
\hline Drug & ED50 & ED75 & ED90 & $\mathrm{Dm}$ & m & $r$ \\
\hline 5-FU & & & & 753.42 & 0.52 & 0.93 \\
\hline HER & & & & $1.42 \mathrm{E}+06$ & 0.05 & 0.43 \\
\hline 5-FU + HER & 226.52 & 173.36 & 132.68 & 488.15 & 0.6 & 0.93 \\
\hline Diagnosis combined effect & antagonism & antagonism & antagonism & & & \\
\hline
\end{tabular}

DOX, Doxorubicin; HER, Herceptin; Cl Combination index.

and can be used in the human. The results from clinical trial with metastic breast cancer patients showed that $21 \%$ efficacy and also increased the efficiency of anticancer drugs [30]. Park et al. reported that HER-2 gene has close relationship with stomach cancer formation and Yonemura et al. suggested that overexpression of HER2 is related to poor prognosis in stomach cancer patients and anti-HER2 antibody may be an essential drug for the therapy [31].

The most efficient therapy of the stomach cancer is surgery. However, recurrence or metastatic recurrence has been found in $80 \%$ patients after surgery, alternative anti-cancer therapy or induced anti-cancer therapy is necessary for the patients after surgery. However, the chemical drugs which have been used in these patients, such as 5-FU, doxorubincin, cisplatin, mitomycin and paclitaxel, showed only $15-30 \%$ efficiency, it is essential to understand the mechanism of stomach cancer formation and develop a new therapy.

In this study, first we analyzed the expression of Her-2 in three stomach cancer cell lines (YBC-2, YBC-3, NCIN87) and found that HER2 is highly expressed in NCIN87. In YBC-3, the expression of HER2 is much weaker and in $\mathrm{YBC}-2$, the expression of this protein is higher than that in YBC-2 but lower than that in NCI-N87. To more clearly analyze the expression of HER-2 in the cells, flow cytometry was used. Doxorubin, cisplatin, paclitaxel and 5-FU four different anticancer drugs were commonly used in chemotherapy and their effects are relatively effective and these compounds have synergic effects when combined with Herceptin in breast cancer therapy. 
In SK-BR-3, the growth inhibitory effect of Herceptin IC40 was observed. This can be explained that the halflife of Herceptin is short (72 hrs), the compound was degraded and not present anymore during MTT assay (96 hrs). Also Herceptin is a cytostatic agent which binds to the growth factor receptor. Although it inhibits HER-2 mediated cell growth pathway, it may induce cell growth through other pathways which there was no difference after increase the dose of compound. In our work, the maximum dose of Herceptin was used and this dose was known effective in breast cancer treatment.

It was found that all of the four compounds could inhibit the growth of cells dose-dependently in SK-BR-3 cells where HER-2 is highly expressed. This data confirmed the relationship between HER-2 expression and doxorubicin efficiency. However, cisplatin didn't dosedependently inhibit cell growth in HER-2 highly expressed NCI-N87 stomach cancer cells. In contrast, it inhibited cell growth in other cell lines. Different from cisplatin and Herceptin, paclitaxel inhibited the growth of cells independent of HER-2 expression. Yu et al. [32]. showed that the cells developed resistant to paclitaxel and Baselga et al. [33]. Showed drugs inhibition need more detailed research is needed.

The synergism, summation and antagonism among Herceptin and other anti-cancer compound is not depends on the expression of HER-2 or the change of phosphorylation [20]. Herceptin single drug has no cytotoxicity in cancer cell in vitro. But by blocking its downstream signaling pathways, to inhibit the cell survival or drug resistance gene expression to achieve synergistic effect in combination therapy. According to previous reports, pretreatment of doxorubicin can increase the expression of EGFR or TGF- $\alpha$ in cells, therefore the combined with anti -EGFR antibody treatment maybe achieve synergy effect in most of cell lines including U87MG cells even that has no or little HER2 expression. This needs forther studies to confirm. Cisplatin induces DNA adduct and inhibits cell growth. It disrupts DNA replication during cell division. If pretreatment the cells with anti-HER2 antibody, the repair efficiency of the DNA breaks which induced by cisplatin is decreased [25]. Paclitaxel also showed dose-dependent efficiency. Chang et al. [31]. showed that paclitaxel causes G2/M phase arrest and also induces cell toxicity in G0/G1 phase [34]. When combination with herceptin, the effect of paclitaxel on $\mathrm{G} 2 / \mathrm{M}$ phase arrest was more efficient and increased the toxicity to the cells. Also Herceptin treatment increased G0/G1 phase cells [35] which increased the sensitivity of the cells to paclitaxel treatment. In the treatment of Herceptin and 5-FU, all the cells showed resistant effect $(\mathrm{CI}>1)$.

In conclusion, in different type of stomach cancer cell lines, the expression of HER-2 protein is different, so different anti-cancer compounds (doxorubicin, cisplatin, paclitaxel and 5-FU) should be used depends on the expression of HER-2. This suggests that HER-2/neu expression level can be applied to standard for drug selection in combination of Herceptin ${ }^{\bullet}$ with chemotherapeutic agents in gastric cancer.

\section{Competing interests}

The authors declare that they have no competing interests.

\section{Authors' contributions}

$\mathrm{HC}$ performed part of the experiments, participate $\mathrm{d}$ in the coordination of the study, and wrote the final manuscript. AHJ performed the main part of the experiments. SZP participated in the experiments and in the coordination of the study. HHS, XC,SNZ, LZP, and YMJ analyzed the data and participated in the experiments. ZHL reviewed the entire manuscript. $\mathrm{ZHL}$ and XHS conceived and designed the study, analyzed the data and helped to draft the manuscript. XHS was responsible for histological examination. All authors read and approved the manuscript.

\section{Acknowledgments}

This work was supported by a special foundation of clinical research from the Chinese Medical Association (2011, No. 14, Dr X.-H.S.), the National Natural Science Foundation of China (81160270 and 81160275), and The Project Sponsored by the Scientific Research Foundation for the Returned Overseas Chinese Scholars, State Education Ministry (2007, X.-H.S.).

\section{Author details}

${ }^{1}$ Department of Oncology, Affiliated Hospital of Yanbian University, Yanji City, Jilin Province, People's Republic of China. 'Jilin Cancer Hospital, Changchun, China. ${ }^{3}$ Department of Pathology, Yanbian University, Yanji, China.

Received: 21 December 2012 Accepted: 20 January 2014

Published: 29 January 2014

\section{References}

1. Yarden $Y$, Sliwkowski MX: Untangling the ErbB signalling network. Nat ReV Mol Cell Biol 2001, 2(2):127-137.

2. Cross M, Dexter TM: Growth factors in development, transformation, and tumorigenesis. Cell 1991, 64(2):271-280.

3. Tal M, Wetzler M, Josefberg Z, Deutch A, Gutman M, Assaf D, Kris R, Shiloh $Y$, Givol D, Schlessinger J: Sporadic amplification of the HER2/neu protooncogene in adenocarcinomas of various tissues. Cancer Res 1988, 48(6):1517-1520.

4. King $\mathrm{CR}$, Kraus $\mathrm{MH}$, Aaronson SA: Amplification of a novel v-erbB-related gene in a human mammary carcinoma. Science 1985, 229(4717):974-976.

5. Slamon DJ, Godolphin W, Jones LA, Holt JA, Wong SG, Keith DE, Levin WJ, Stuart SG, Udove J, Ullrich A, et al: Studies of the HER-2/neu proto-oncogene in human breast and ovarian cancer. Science 1989, 244(4905):707-712.

6. Reese DM, Slamon DJ: HER-2/neu signal transduction in human breast and ovarian cancer. Stem Cells 1997, 15(1):1-8.

7. Hung MC, Lau YK: Basic science of HER-2/neu: a review. Semin Oncol 1999, 26(4 Suppl 12):51-59.

8. Sahin AA: Biologic and clinical significance of HER-2/neu (cerbB-2) in breast cancer. Adv Anat Pathol 2000, 7(3):158-166.

9. Doss S, Robertson J, Adam J: Lapatinib or trastuzumab in combination with an aromatase inhibitor for first-line treatment of metastatic hormone-receptor-positive breast cancer that overexpresses HER2. Lancet Oncol 2012, 13(8):766-767.

10. McCaughan H, Um I, Langdon SP, Harrison DJ, Faratian D: HER2 expression in ovarian carcinoma: caution and complexity in biomarker analysis. J Clin Pathol 2012, 65(7):670-671. author reply 671-672.

11. Yan B, Choo SN, Mulyadi P, Srivastava S, Ong CW, Yong KJ, Putti T, Salto-Tellez M, Lim GS: Dual-colour HER2/chromosome 17 chromogenic in situ hybridisation enables accurate assessment of HER2 genomic status in ovarian tumours. J Clin Pathol 2011, 64(12):1097-1101.

12. Dai GH, Shi $Y$, Chen $L$, Lv YL, Zhong M: Trastuzumab combined with docetaxel-based regimens in previously treated metastatic gastric cancer patients with HER2 over-expression. Hepatogastroenterology 2012, 59(120):2439-2444 
13. Liu AN, Sun P, Liu JN, Ma JB, Qu HJ, Zhu H, Yu CY, Zhang LM: Clinicopathologic characteristics and prognostic factors in patients with operable HER-2 overexpressing breast cancer. Asian Pac J Cancer Prev 2012, 13(4):1197-1201.

14. Steffensen KD, Waldstrom M, Brandslund I, Jakobsen A: Prognostic impact of prechemotherapy serum levels of HER2, CA125, and HE4 in ovarian cancer patients. Int J Gynecol Cancer 2011, 21(6):1040-1047.

15. Janjigian YY, Werner D, Pauligk C, Steinmetz K, Kelsen DP, Jager E, Altmannsberger HM, Robinson E, Tafe LJ, Tang LH, et al: Prognosis of metastatic gastric and gastroesophageal junction cancer by HER2 status: a European and USA International collaborative analysis. Ann Oncol 2012, 23(10):2656-2662

16. Ignatoski KM, Maehama T, Markwart SM, Dixon JE, Livant DL, Ethier SP: ERBB-2 overexpression confers PI 3' kinase-dependent invasion capacity on human mammary epithelial cells. Br J Cancer 2000, 82(3):666-674.

17. Hashimoto K, Yamamoto H, Shiratsuchi H, Nakashima T, Tamiya S, Nishiyama K, Higaki Y, Komune S, Tsuneyoshi M, Oda Y: HER-2/neu gene amplification in carcinoma ex pleomorphic adenoma in relation to progression and prognosis: a chromogenic in-situ hybridization study. Histopathology 2012, 60(6B):E131-E142.

18. Zhang YF, Guan YB, Yang B, Wu HY, Dai YT, Zhang SJ, Wang JP, Anoopkumar-Dukie S, Davey AK, Sun ZY: Prognostic value of Her-2/neu and clinicopathologic factors for evaluating progression and diseasespecific death in Chinese men with prostate cancer. Chin Med J (Engl) 2011, 124(24):4345-4349

19. Renner C, Zemitzsch N, Fuchs B, Geiger KD, Hermes M, Hengstler J, Gebhardt R, Meixensberger J, Gaunitz F: Carnosine retards tumor growth in vivo in an NIH3T3-HER2/neu mouse model. Mol Cancer 2010, 9:2.

20. Pegram M, Hsu S, Lewis G, Pietras R, Beryt M, Sliwkowski M, Coombs D, Baly D, Kabbinavar F, Slamon D: Inhibitory effects of combinations of HER-2/neu antibody and chemotherapeutic agents used for treatment of human breast cancers. Oncogene 1999, 18(13):2241-2251.

21. Yan SY, Hu Y, Fan JG, Tao GQ, Lu YM, Cai X, Yu BH, Du YQ: Clinicopathologic significance of HER-2/neu protein expression and gene amplification in gastric carcinoma. World J Gastroenterol 2011, 17(11):1501-1506.

22. Wang S, Zheng G, Chen L, Xiong B: Effect of HER-2/neu over-expression on prognosis in gastric cancer: a meta-analysis. Asian Pac J Cancer Prev 2011, 12(6):1417-1423.

23. Sliwkowski MX, Lofgren JA, Lewis GD, Hotaling TE, Fendly BM, Fox JA: Nonclinical studies addressing the mechanism of action of trastuzumab (Herceptin). Semin Oncol 1999, 26(4 Suppl 12):60-70.

24. Baselga J, Tripathy D, Mendelsohn J, Baughman S, Benz CC, Dantis L, Sklarin NT, Seidman AD, Hudis CA, Moore J, et al: Phase II study of weekly intravenous trastuzumab (Herceptin) in patients with HER2/neuoverexpressing metastatic breast cancer. Semin Oncol 1999, 26(4 Suppl 12):78-83.

25. Pegram MD, Slamon DJ: Combination therapy with trastuzumab (Herceptin) and cisplatin for chemoresistant metastatic breast cancer: evidence for receptor-enhanced chemosensitivity. Semin Oncol 1999, 26(4 Suppl 12):89-95.

26. Revillion F, Bonneterre J, Peyrat JP: ERBB2 oncogene in human breast cancer and its clinical significance. Eur J Cancer 1998, 34(6):791-808.

27. Wang SL, Li YX, Song YW, Wang WH, Jin J, Liu YP, Liu XF, Yu ZH: Triplenegative or HER2-positive status predicts higher rates of locoregional recurrence in node-positive breast cancer patients after mastectomy. Int J Radiat Oncol Biol Phys 2011, 80(4):1095-1101.

28. Ren H, Li J, Liu JJ, Guo HL, Jiang T: Anti-HER-2 anti-CD3 Bi-specific Antibodies Inhibit Growth of HCT-116 Colorectal Carcinoma Cells in Vitro and in Vivo. Asian Pac J Cancer Prev 2012, 13(6):2795-2798.

29. Plowman GD, Culouscou JM, Whitney GS, Green JM, Carlton GW, Foy L, Neubauer MG, Shoyab M: Ligand-specific activation of HER4/p180erbB4, a fourth member of the epidermal growth factor receptor family. Proc Natl Acad Sci USA 1993, 90(5):1746-1750.

30. Slamon DJ, Leyland-Jones B, Shak S, Fuchs H, Paton V, Bajamonde A, Fleming T, Eiermann W, Wolter J, Pegram M, et al: Use of chemotherapy plus a monoclonal antibody against HER2 for metastatic breast cancer that overexpresses HER2. N Engl J Med 2001, 344(11):783-792.

31. Chang YF, Li LL, Wu CW, Liu TY, Lui WY, P'Eng FK, Chi CW: Paclitaxelinduced apoptosis in human gastric carcinoma cell lines. Cancer 1996 77(1):14-18.
32. Baselga J, Seidman AD, Rosen PP, Norton L: HER2 overexpression and paclitaxel sensitivity in breast cancer: therapeutic implications. Oncology (Williston Park) 1997, 11(3 Suppl 2):43-48.

33. Yu D, Liu B, Tan M, Li J, Wang SS, Hung MC: Overexpression of c-erbB-2/ neu in breast cancer cells confers increased resistance to Taxol via mdr1-independent mechanisms. Oncogene 1996, 13(6):1359-1365.

34. Costantini DL, Villani DF, Vallis KA, Reilly RM: Methotrexate, paclitaxel, and doxorubicin radiosensitize HER2-amplified human breast cancer cells to the Auger electron-emitting radiotherapeutic agent (111)In-NLS-trastuzumab. J Nucl Med 2010, 51(3):477-483.

35. Chou TC, Motzer RJ, Tong Y, Bosl GJ: Computerized quantitation of synergism and antagonism of taxol, topotecan, and cisplatin against human teratocarcinoma cell growth: a rational approach to clinical protocol design. J Natl Cancer Inst 1994, 86(20):1517-1524.

doi:10.1186/1475-2867-14-10

Cite this article as: Cui et al:: Correlation between HER-2/neu(erbB-2) expression level and therapeutic effect of combination treatment with HERCEPTIN and chemotherapeutic agents in gastric cancer cell lines. Cancer Cell International 2014 14:10.

\section{Submit your next manuscript to BioMed Central and take full advantage of:}

- Convenient online submission

- Thorough peer review

- No space constraints or color figure charges

- Immediate publication on acceptance

- Inclusion in PubMed, CAS, Scopus and Google Scholar

- Research which is freely available for redistribution

Submit your manuscript at www.biomedcentral.com/submit
C) Biomed Central 